\title{
MONITORING AND ECOLOGICAL-AND-HYGIENIC EVALUATION OF THE QUALITY OF DRINKING WATER FROM THE SOURCES OF DECENTRALIZED WATER SUPPLY IN RIVHE REGION FOR 2004-2015
}

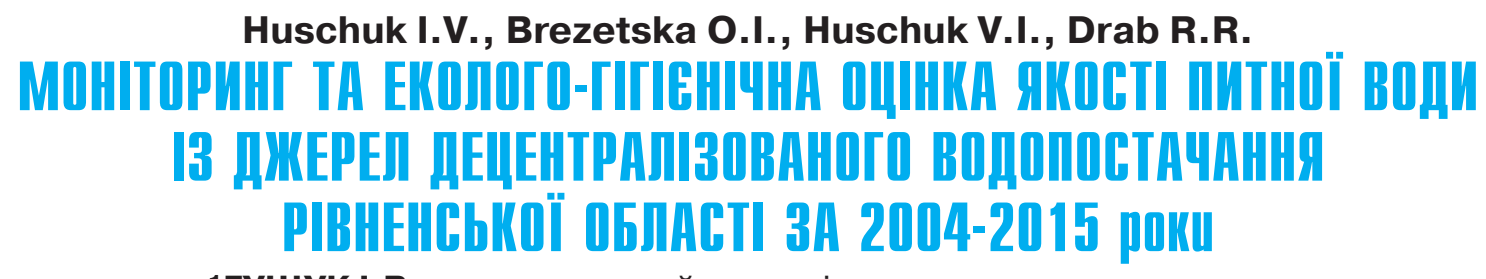

1ГУЩУК І.В., 2 БРЕЗЕЦЬКА О.І., 2ГУЩУК В.І., 2ДРАБ Р.Р. 1 НДЦ «Екологія людини та охорона громадського здоров'я» Національного університету

«Острозька академія», м. Острог, Україна 2Ду "Рівненський обласний лабораторний центр" МОЗ

України, м. Рівне, Україна

УДК 614.777

Ключові слова: питна вода, децентралізоване водопостачання, показники якості води.

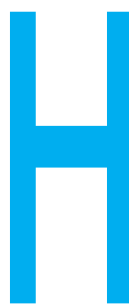

айважливіше завдання сучасності раціональне використання й охорона природних ресурсів, у тому числі забезпечення населення доброякісною питною водою. Загальновідомо, що без води неможливе життя, вона є однією із головних складових існування людства, а також вагомим чинником, який впливає на людське здоров'я на індивідуальному та популяційному рівнях.

Світовою спільнотою на початку XXI століття право на воду та санітарію було визнане як базове право людини. За даними ВООЗ [1], близько 800 млн. населення планети не мають доступу до води належної якості, і щоденно понад 3000 дітей помирають через діарейні захворювання, а щорічно у світі через такі захворювання помирають близько 2,5 млн. людей, половина з яких діти до 5 років.

Погіршення соціально-економічних умов, екологічної ситуації і фактично відсутність належного системного соціально-гігієнічного моніторингу за факторами середовища життєдіяльності несе реальні загрози для життя і здоров'я населення на індивідуальному та популяційному рівнях.

У контексті розбудови системи охорони громадського здо-
МОНИТОРИНГ И ЭКОЛОГО-ГИГИЕНИЧЕСКАЯ ОЦЕНКА КАЧЕСТВА ПИТЬЕВОЙ ВОДЫ ИЗ ИСТОЧНИКОВ ДЕЦЕНТРАЛИЗОВАННОГО ВОДОСНАБЖЕНИЯ РОВЕНСКОЙ ОБЛАСТИ ЗА 2004-2015 ГОДЫ

1 Гущук И.В., 2 Брезецкая О.И., 2 Гущук В.И., 2 Драб Р.P.

1 НИЦ «Экология человека и охрана общественного здоровья» Национального университета «Острожская академия», г. Острог, Украина

2 Государственное учреждение "Ровенский областной лабораторный центр" МЗ Украины, г. Ровно, Украина

В работе приведены данные о качестве питьевой воды из децентрализованных источников водоснабжения Ровенской области, единственной из областей Украины, где водообеспечение населения питьевой водой осуществляется из подземных водоносных горизонтов. Материалы собраны и проанализированы за 2004-2015 годы на соответствие питьевой воды санитарнохимическим и санитарно-микробиологическим показателям в разрезе районов.

Целью работы является оценка эколого-гигиени ческого состояния качества питьевой воды из источников децентрализованного водоснабжения Ровенской области в течение 2004-2015 годов. Материалы и методы. В работе использовались данные лабораторных исследований по санитарно-химическим, микробиологическим, паразитологическим и радиологическим показателям. Систематизация, обработка и анализ материалов исследований осуществлялись с помощью описательного, динамического и сравнительных методов.

Результаты исследований. Установлено, что в области с 2004 по 2015 годы количество источников децентрализованного водоснабжения уменьшилось на 197 единиц, в том числе колодцев - с 1347 до 1147(-200), каптажей - с 10 до 8(-2), артезианских колодцев - с 2 до 7(+5).

Уменьшение в основном произошло за счет прекращения эксплуатации колодцев общественного пользования. Среднеобластной показатель несоответствия питьевой воды из источников децентрализованного водоснабжения по санитарнохимическим показателям за исследуемый период увеличился более чем в 2,5 раза, с 14,5\% в 2004 г. до 40,0\% в 2015 г. Следует отметить резкий рост процента несоответствия проб за последние два года - от 21,2\% в 2013 г. до 40,0\% в 2015 г. По микробиологическим показателям среднеобластной показатель несоответствия вырос на 3,2\% и составил в 2015 г. 29,0\% при 25, 8\% в 2004 г. Особо следует отметить резкое увеличение процента несоответствия проб за последние 2 года, с 14,0\% в 2013 г. до 29,0\% в 2015 г.

Вывод. Полученные результаты свидетельствуют, что в контексте развития системы общественного здоровья в Украине необходимо продолжить работу по определению корреляционных взаимосвязей между качеством питьевой воды и состоянием заболеваемости населения области.

Ключевые слова: Ровенская область, децентрализованное водоснабжение, микробиологические показатели, санитарно-химические показатели, питьевая вода, показатели качества воды, система общественного здоровья.

() Гущук I.В., Брезецька О.І., Гущук В.І., Драб Р.Р. СТАТТЯ, 2018.

41 Devirovinevi \& II:an/II № 12018 
ров'я в Україні питання щодо забезпечення населення безпечною питною водою $€$ надзвичайно актуальним [2].

Метою роботи $€$ оцінка еколого-гігієнічного стану якості питної води із джерел децентралізованого водопостачання Рівненщини за 2004-2015 роки.

Матеріали та методи. У роботі використовувалися дані лабораторних досліджень за санітарно-хімічними, мікробіологічними, паразитологічними та радіологічними показниками ф. 18 "Звіт про фактори навколишнього середовища,

Середньообласний показник невідповідності пи (\%) із джерел децентралізованого та централізованого водопостачання за санітарно-хімічними показниками у період з 2004 по 2015 роки

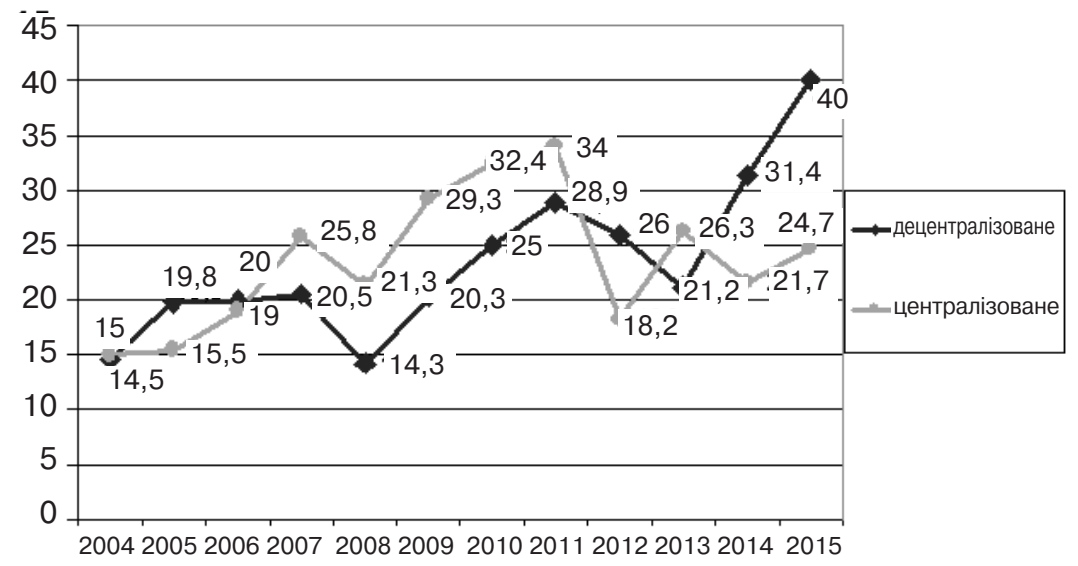

шилася на 197 одиниць, у тому числі колодязів - з 1347 до $1147(-200)$, каптажів - 310 до 8 (-2), артезіанських колодязів з 2 до $7(+5)$. Зменшення відбулося переважно за рахунок припинення експлуатації колодязів громадського користування.

Середньообласний показник невідповідності питної води із джерел децентралізованого водопостачання за санітарнохімічними показниками за досліджуваний період збільшився більше ніж у 2,5 рази: 3 $14,5 \%$ у 2004 році до $40,0 \%$ у 2015. Слід відзначити різке зростання відсотка невідповідності проб за останні 2 роки 3 $21,2 \%$ у 2013 р. до $40,0 \%$ у 2015 р. (рис. 1).

Вище за середньообласний цей показник був у Володимирецькому, Гощанському, Здолбунівському, Корецькому, Костопільському та Радивилівському районах (табл. 1). Перевищення в основному відзначалося переважно за вмістом заліза, нітратів та каламутністю.

Аналізуючи динаміку невідповідності проб питної води із джерел децентралізованого водопостачання за санітарнохімічними показниками у розрізі районів за період з 2004 по 20015 роки, встановлено:

Таблиця 1

Відсоток невідповідності проб питної води із джерел децентралізованого водопостачання за санітарно-хімічними показниками у динаміці за 2004-2015 роки

\begin{tabular}{|l|c|c|c|c|c|c|c|c|c|c|c|c|}
\hline \multicolumn{1}{|c|}{ Район (місто) } & \multicolumn{10}{|c|}{ \% невідповідності } \\
\hline & 2004 & 2005 & 2006 & 2007 & 2008 & 2009 & 2010 & 2011 & 2012 & 2013 & 2014 & 2015 \\
\hline Березнівський & 20,8 & 24,28 & 17,8 & 8,6 & 8,5 & 25 & 26,4 & 54,8 & 37,7 & 70 & 26,1 & 1,9 \\
\hline Володимирецький & 20,6 & 24 & 35,6 & 19 & 16,8 & 31 & 31,0 & 68,1 & 65,2 & 51,7 & 40,9 & 43,8 \\
\hline Гощанський & 10,3 & 5,4 & 3,03 & 1,9 & 5,8 & 7,1 & 30,4 & 33,3 & 46,9 & 38,9 & 53,8 & 62,7 \\
\hline Дубенський & 11,2 & 31,2 & 38,2 & 13,6 & 30,8 & 28 & 3,4 & 35,1 & 33,5 & 35,8 & 34,8 & 27,1 \\
\hline Дубровицький & 15,7 & 25 & 61,02 & 31,7 & 16,1 & 72,9 & 48,9 & 28,7 & 26,1 & 13,6 & 20,3 & 22,6 \\
\hline Зарічненський & 15,6 & 23,3 & 12,5 & 9,2 & 7,3 & 16,7 & 4,6 & 2,3 & 3,3 & 3,2 & 14,4 & 4,4 \\
\hline Здолбунівський & 12,9 & 11,4 & 16,5 & 35,4 & 9,8 & 15,1 & 24,0 & 21,1 & 34,1 & 18,2 & 0 & 77,8 \\
\hline Корецький & 9,9 & 8,87 & 9,5 & 11,7 & 10,5 & 3,1 & 17,6 & 14,8 & 7,9 & 2,1 & 49,8 & 68,1 \\
\hline Костопільський & 22,0 & 16 & 42,42 & 61,5 & 38,2 & 45,5 & 42,4 & 45,4 & 42,4 & 9,3 & 15,8 & 41,3 \\
\hline Млинівський & 18,5 & 20 & 14,4 & 14,9 & 14,7 & 15 & 16,0 & 0 & 10,4 & 5,9 & 7,3 & 25,5 \\
\hline Острозький & 7,3 & 3,57 & 13,6 & 6,6 & 7,5 & 9,4 & 21,2 & 24 & 13,5 & 33,3 & 22,1 & 29,5 \\
\hline Радивилівський & 6,5 & 12,3 & 11,7 & 13,6 & 16 & 12,2 & 31,1 & 28,8 & 17,5 & 33,3 & 27,3 & 58,1 \\
\hline Рівненський & 43,7 & 65 & 26,9 & 45 & 20 & 26,1 & 38,5 & 42,5 & 31,2 & 100 & - & - \\
\hline Рокитнівський & 3,9 & 8,33 & 4,8 & 7,4 & 6,5 & 7,7 & 7,1 & 16,7 & 10,2 & 1,5 & 24,7 & 23,3 \\
\hline Сарненський & 23,8 & 56,25 & 28,6 & 61 & 40,8 & 19,2 & 16,8 & 23,9 & 21,8 & 24,2 & 24,8 & 30,3 \\
\hline м. Рівне & - & - & - & - & - & - & - & - & - & - & - & - \\
\hline м. Кузнецовськ & - & - & - & - & - & - & - & - & - & - & - & - \\
\hline Загалом & 14,5 & 19,8 & 19,98 & 20,5 & 14,3 & 20,3 & 25 & 28,9 & 26 & 21,2 & 31,4 & 40,0 \\
\hline
\end{tabular}


MONITORING AND ECOLOGICAL-AND-HYGIENIC EVALUATION OF THE QUALITY OF DRINKING WATER FROM THE SOURCES OF DECENTRALIZED WATER SUPPLY IN RIVNE REGION FOR 2004-2015

1 Huschuk I.V., 2 Brezetska O.I., 2 Huschuk V.I., 2 Drab R.R.

1 SRC "Human Ecology and Public Health", National University "Ostroh Academy", Ostroh, Ukraine

2 State Institution "Rivne Regional Laboratory Center", Ministry of Health of Ukraine, Rivne, Ukraine

There are the data on the quality of drinking water from decentralized sources of water supply in Rivne oblast, one of the oblasts of Ukraine, where the water supply of the population with drinking water is carried out from the underground aquifers. The materials were collected and analyzed on the compliance of drinking water with sanitary-chemical and sanitary-microbiological indicators in the districts for the period of 2004-2015. Objective. We assessed the ecological and hygienic state of the quality of drinking water from the sourcesof decentralized water supply in Rivne region during 2004-2015.

Materials and methods. The laboratory data on the sanitary-chemical, microbiological, parasitological and radiological indices were used in the work.

Systematization, processing and analysis of the research materials were carried out with the help of descriptive, dynamic and comparative methods. Results. Since 2004-2015, a number of the sources of decentralized water supply, including wells from 1347 to $1147(-200)$, captures from 10 to 8(-2) and artesian wells from 2 to $7(+5)$ was stated to be decreased by 197 units in the oblast. The decrease was mainly due to the discontinuation of public wells' exploitation. The average regional indicator of non-compliance of drinking water from the sources of decentralized water supply in terms of sanitary and chemical indicators was increased more than 2.5 times in the period under study from $14.5 \%$ in 2004 up to $40.0 \%$ in 2015 . In recent 2 years a sharp increase in the percentage of non-compliance of the samples was noted from $21.2 \%$ in 2013 up to $40.0 \%$ in 2015.

According to the microbiological indices, the average non-compliance rate for the above-mentioned period grew by $3.2 \%$ and amounted to $29.0 \%$ in 2015 at $25.8 \%$ in 2004 . The sharp increase in the percentage of non-compliance of samples was noted in recent 2 years from $14.0 \%$ in 2013 up to $29.0 \%$ in 2015.

Conclusion. The obtained results show that in the context of the development of the public health system in Ukraine it is necessary to continue the work on the determination of the correlation between the quality of drinking water and the state of morbidity in the oblast.

\section{Keywords: Rivne oblast, decentralized water} supply, microbiological indicators, sanitary-andchemical indicators, drinking water, water quality indicators, public health system. у Березнівському районі відсоток невідповідності різко знизився до $26,1 \%$ і 1,9\% відповідно. Загалом у динаміці за 12 років спостерігається зниження відсотка невідповідності проб питної води із джерел децентралізованого водопостачання за санітарно-хімічними показниками 3 20,8\% до $1,9 \%$;

$\square$ у Володимирецькому районі за увесь період дослідження відсоток невідповідності був вищим за середньообласний показник (за виключенням 2007 року) і зріс у 2,1 рази 3 20,6\% до 43,8\%;

у Гощанському районі відсоток невідповідності зріс у 6 разів, з 10,3\% до 62,7\%. 32010 року відзначається різке погіршення проб питної води із джерел децентралізованого водопостачання за санітарно-хімічними показниками;

$\square$ у Дубенському районі відсоток невідповідності зріс у 2,5 рази, $з$ 11,2\% до 27,1\%. Слід зазначити, що за 2015 рік відсоток невідповідності проб був значно нижчим за середньообласний;

口 д Дубровицьому районі відсоток невідповідності зріс в 1,5 рази, $з 15,7 \%$ до $22,6 \%$. Однак за останні роки відзначається позитивна тенденція до зниження вказаного показника порівняно 3 середньо- обласним значенням;

у З Зарічнянському районі спостерігається зниження відсотка невідповідності проб $з$ $15,7 \%$ до $4,4 \%$, тобто більше ніж у 3 рази. 32006 року відсоток невідповідності не перевищував середньообласний показник;

घy Здолбунівському районі за останій рік відсоток невідповідності різко збільшився та становив $77,8 \%$, що майже вдвічі перевищувало середньообласний показник. При цьому у 2014 році невідповідності проб води встановленим нормативам зафіксовано не було;

$\square$ у Корецькому районі за

\section{Середньообласний показник невідповідності питної води (\%) із джерел децентралізованого та централізованого водопостачання за мікробіологічними показниками у період з 2004 по 2015 рік \\ Рисунок 2}

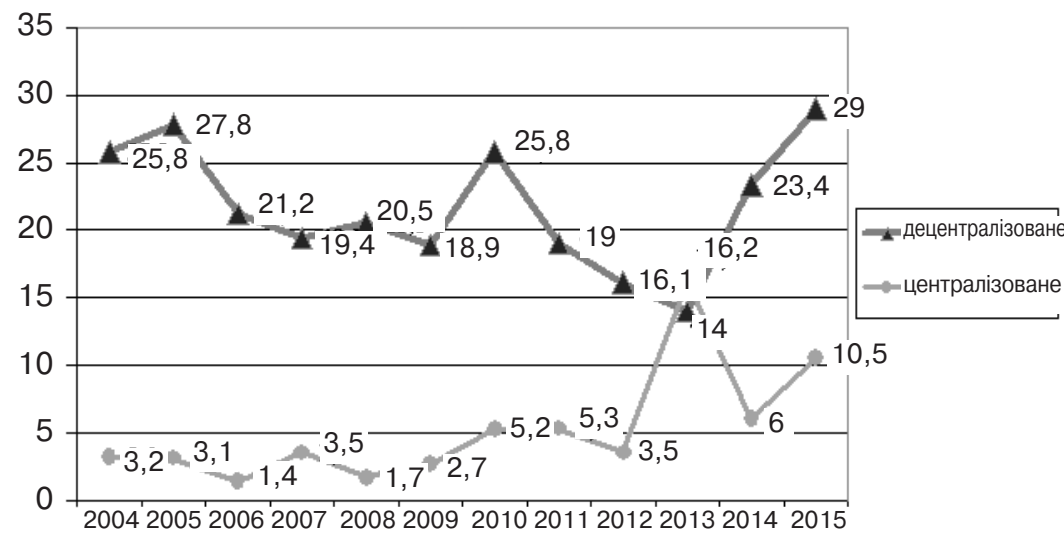

увесь період дослідження відостанні 2 роки вказаний показник різко збільшився й становив $49,8 \%$ у 2014 році та $68,1 \%$ у 2015 порівняно з середньообласним значенням 31,4\% та 40\% відповідно;

$\square$ у Костопільському районі відсоток невідповідності зріс майже у 2 рази, $з$ 22,0\% до 41,3\%. Слід відзначити, що цей показник практично щороку був вищим за середньообласний (за виключенням 2005, 2013-2014 років);

$\square$ у Млинівському районі відсоток невідповідності зріс в 1,3 соток невідповідності проб зріс 
нітарно-хімічними показниками не проводилися;

口 у Рокитнівському районі відсоток невідповідності зріс з $3,9 \%$ до 23,3\%, майже у 6 разів. Разом $з$ цим, Рокитнівський район - єдиний в області, де відсоток невідповідності за останні 12 років жодного разу не перевищував середньообласний показник;

$\square$ у Сарненському районі відсоток невідповідності зріс в 1,3 рази, з 23,8\% до $30,3 \%$.

При порівнянні якості питної води із артезіанських свердловин централізованих водопроводів та криниць відзначається перевищення середньообласного показника невідповідності із джерел централізованого водопостачання над показником із криниць у 2006-2011 та 2013 роках (рис. 1).

За даними наших досліджень встановлено, що невідповідність якості питної води нормативним вимогам за санітарнохімічними показниками спричинена переважно через перевищення вмісту заліза (як наслідок значної каламутності) та нітратів. При цьому слід відзначити: якщо показники природного вмісту заліза не є критичними з точки зору токсикологічного впливу, то перевищення вмісту нітратів $€$ шкідливим, особливо для дітей пер- ших років життя. Нітрати не належать до метгемоглобінутворювачів, але надходячи до шлунка з водою, під впливом кишкової мікрофлори відновлюються у нітрити з подальшим утворенням метгемоглобіну, що, у свою чергу, блокує здатність перенесення кисню по організму. Метгемоглобін стійкіший за оксигемоглобін за ступенем дисоціації у 300, а за деякими даними - у 500 разів. Якщо кількість метгемоглобіну перевищує $50 \%$ загального гемоглобіну, організм може загинути через гіпоксію ЦНС. У нормі у дітей середнього віку концентрація метгемоглобіну у крови не має перевищувати 1-2\%. Перевищення вмісту нітратів більш ніж 45 мг на 1 л може спричинити воднонітратну метгемоглобінемію, особливо серед дітей, клінічний прояв якої - акроціаноз (посиніння носу, верхньої губи, так званого трикутника, мочки вух, кінчиків пальців, тахікардія, задишка, ціаноз слизових оболонок, запалення, судоми) [36]. При цьому, як свідчать останні наукові дослідження, тривале надходження низьких концентрацій може викликати у дітей безсимптомну метгемоглобінемію, яка $€$ небезпечною для їхнього здоров'я, оскільки викликає гемічну та гістотокроки дослідження пецентрал ваного водопостачання за са-

Таблиця 2 Відсоток невідповідності проб питної води із джерел децентралізованого водопостачання за мікробіологічними показниками у динаміці за 2004-2015 роки

\begin{tabular}{|l|c|c|c|c|c|c|c|c|c|c|c|c|}
\hline \multirow{2}{*}{ Район (місто) } & \multicolumn{10}{|c|}{ \% невідповідності } \\
\cline { 2 - 13 } & 2004 & 2005 & 2006 & 2007 & 2008 & 2009 & 2010 & 2011 & 2012 & 2013 & 2014 & 2015 \\
\hline Березнівський & 7,1 & 14,95 & 16,8 & 12,9 & 11,6 & 14,3 & 3,4 & 1,4 & 6,9 & 7,4 & 15 & 0 \\
\hline Володимирецький & 39,2 & 42,5 & 48,9 & 36,9 & 40,0 & 42,9 & 56,9 & 41,3 & 32,2 & 53,3 & 51,4 & 53,8 \\
\hline Гощанський & 43,3 & 47,2 & 9,4 & 38,9 & 34,5 & 16,4 & 84,1 & 12,1 & 28,6 & 30 & 44,4 & 58,3 \\
\hline Дубенський & 36,5 & 31,3 & 12,9 & 2,04 & 23,5 & 38 & 31,2 & 21,4 & 34,1 & 25,6 & 36,6 & 20 \\
\hline Дубровицький & 14,2 & 52,08 & 27,8 & 27,8 & 13,4 & 15,7 & 12,7 & 7,2 & 3,9 & 14,3 & 3,4 & 4,5 \\
\hline Зарічненський & 16,1 & 27,2 & 12,5 & 24 & 1,2 & 3,9 & 14,3 & 3,6 & 9,4 & 3 & 7,5 & 13,3 \\
\hline Здолбунівський & 48,3 & 74,6 & 46,7 & 43,1 & 53,5 & 44,4 & 26,8 & 42,4 & 37 & 37,5 & - & 62,5 \\
\hline Корецький & 13,2 & 14,3 & 10,2 & 8,9 & 13,3 & 8,96 & 7,6 & 7,6 & 8,2 & 18,3 & 18,7 & 11,1 \\
\hline Костопільський & 21,5 & 38,2 & 55,9 & 53,8 & 46,0 & 39,4 & 45,4 & 56,2 & 12,1 & 30,8 & 69 & 83,3 \\
\hline Млинівський & 40,9 & 9,4 & 5,9 & 4,9 & 5,1 & 6,4 & 3,6 & 26,5 & 31,7 & 20,8 & 44,4 & 18,2 \\
\hline Острозький & 13,5 & 6,66 & 17,5 & 13,9 & 26,4 & 8,3 & 20,0 & 13,2 & 14,5 & 24,4 & 46 & 33,9 \\
\hline Радивилівський & 15,1 & 20 & 14,7 & 17,8 & 10,4 & 12,6 & 13,4 & 11,8 & 10 & 16,7 & 14,3 & 6,7 \\
\hline Рівненський & 22,9 & 42,8 & 39,6 & 26,9 & 34,0 & 38,1 & 40,7 & 45,4 & 53,8 & 81,8 & - & - \\
\hline Рокитнівський & 36,0 & 26,0 & 16,6 & 19,7 & 17,7 & 17,1 & 14,6 & 11,4 & 4,1 & 0,8 & 11,1 & 8,3 \\
\hline Сарненський & 25,4 & 47,6 & 24,1 & 15,6 & 21,8 & - & 62,5 & 22,5 & 19,5 & 5,7 & 30,9 & 66,7 \\
\hline м. Рівне & - & - & - & - & - & - & - & - & - & - & - & 93,7 \\
\hline м. Кузнецовськ & - & - & - & - & - & - & - & - & - & - & 4,1 & - \\
\hline Загалом & 25,8 & 27,8 & 21,2 & 19,4 & 20,5 & 18,9 & 25,8 & 19,0 & 16,1 & 14 & 23,4 & 29,0 \\
\hline
\end{tabular}


сичну гіпоксію [7]. Також слід зауважити, що у поєднанні 3 комбінованою дією інших забруднювачів довкілля нітратовмісні сполуки можуть справляти негативний імунний ефект на живий організм [8].

При систематизації та аналізі даних досліджень питної води із джерел децентралізованого водопостачання за мікробіологічними показниками встановлено, що середньообласний показник невідповідності за вищевказаний період зріс на $3,2 \%$ і становив у 2015 р. $29,0 \%$ при 25,8\% у 2004 р. [2]. Слід відзначити різке зростання відсотка невідповідності проб за останні 2 роки, з 14,0\% у 2013 році до 29,0\% у 2015 (рис. 2).

Вище за середньообласний відсоток невідповідності питної води із джерел децентралізованого водопостачання за мікробіологічними показниками визначався у Володимирецькому, Гощанському, Здолбунівському, Костопільському, Острозькому, Сарненському районах та у м. Рівне (табл. 2).

Нижче наведено ситуацію у розрізі районів за невідповідністю проб питної води із джерел децентралізованого водопостачання за мікробіологічними показниками за період з 2004 по 2015 рік:

$\square$ у Березнівському районі 3 2004 до 2014 року відсоток невідповідності проб зріс у 2 рази, $з 7,1 \%$ до 15\%. Слід зазначити, що у даному районі, єдиному в області, за досліджуваний період вказаний показник не перевищував середньообласний. У 2015 році невідповідності проб питної води зафіксовано не було;

$\square$ у Володимирецькому районі відсоток невідповідності за 12 років зріс в 1,2 рази, з 39,2\% до 53,8\%. Зауважимо, що цей показник щороку перевищував середньообласний;

口 Гощанському районі за досліджуваний період відсоток невідповідності зріс на 15\%, 3 43,3\% до 58,3\%;

口у Дубенському районі відсоток невідповідності коливається у межах $(30+10) \%$, за винятком 2006-2007 років. На 2015 рік цей показник зменшився в 1,7 рази, з 36,5\% до 20\%;

口 д Дубровицькому районі в останні роки відзначається зниження відсотка невідповідності з 14,2\% до 4,5\%;

- у Зарічнянському районі за період дослідження відсоток невідповідності знизився на 2,1\%, з 16,1\% до 13,3\%;

$\square$ у Здолбунівському районі відсоток невідповідності зріс в 1,2 рази, 3 48,3\% до $62,5 \%$. щороку цей показник перевищував середньообласне значення;

у К Корецькому районі за період дослідження відсоток невідповідності знизився на $2,1 \%, з$ з $13,2 \%$ до $11,1 \%$;

$\square$ у Костопільському районі за 12 років відсоток невідповідності зріс майже у 4 рази, 3 $21,5 \%$ до $83,3 \%$;

घ Млинівському районі 3 року в рік фіксуються різкі коливання відсотка невідповідності проб питної води із джерел децентралізованого водопостачання за мікробіологічними показниками. За досліджуваний період даний показник зменшився більше ніж у 2 рази, з 40,9\% до 18,2\%;

$\square$ в Острозькому районі загалом за період дослідження відсоток невідповідності збільшився вдвічі, з 13,5\% до 33,9\%. В останні 3 роки цей показник значно перевищував середньообласний

$\square$ у Радивилівському районі відсоток невідповідності проб не перевищував 20\%. 32004 року цей показник знизився у 2,5 рази, з 15,2\% до 6,7\% ;

$\square$ у Рівненському районі відсоток невідповідності показникам зріс у 3,8 рази, з 22,9\% до $81, \%$ у 2013 році. Даний показник щороку перевищував середньообласне значення. У 2014-2015 роках дослідження проб питної води із джерел децентралізованого водопостачання за мікробіологічними показниками не проводилися;

$\square$ у Рокитнівському районі відзначається практично щорічне зниження відсотка невідповідності, який знизився більше ніж у 4 рази, з 36,0\% до 8,3\%;

у С Сарненському районі за досліджуваний період даний показник зріс більше ніж вдвічі, з $25,4 \%$ до $66,7 \%$;

$\square$ у м. Рівне дослідження проб питної води із джерел децентралізованого водопостачання за мікробіологічними показниками проводилося лише у 2014 році. Відсоток невідповідності становив 93,7\%;

口у м. Кузнецовськ (нині Вараш) дослідження проб питної води із джерел децентралізованого водопостачання за мікробіологічними показниками проводилося лише у 2013 році. Відсоток невідповідності становив $4,1 \%$.

При порівнянні середньообласного відсотка невідповідності якості питної води із артезіанських свердловин централізованих водопроводів та криниць за мікробіологічними показниками відзначається значне його перевищення із криниць, ніж із джерел централізованого водопостачання протягом досліджуваного періоду (рис. 2).

На даний час нами проведено дослідження якості питної води за санітарно-хімічними та мікробіологічними показниками із джерел та мережі централізованих водопроводів у розрізі районів Рівненської області за 1999-2015 роки [9]. Спільно з фахівцями ДУ «Інститут громадського здоров'я ім. О.М. Марзєєва НАМНУ» проводяться роботи 3 вивчення рівня захворюваності населення Рівненської області та визначення кореляційних взаємозв'язків між якістю питної води та станом захворюваності міського та сільського населення [10].

\section{Висновки}

1. За останні десятиріччя кількість джерел децентралізованого водопостачання в області зменшилася на $12 \%$.

2. Середньообласний показник невідповідності проб питної води із джерел децентралізованого водопостачання за санітарно-хімічними характеристиками за 12 років збільшився більше ніж у 2,5 рази, 3 $14,5 \%$ у 2004 р. до $40,0 \%$ у $2015 \mathrm{p}$.

3. Якість питної води за санітарно-хімічними показниками погіршується у джерелах децентралізованого водопостачання переважно через підвищений вміст заліза, нітратів та каламутність. 
рамок діяльності Співтовариства у галузі водної політики" від 23.10.2000 р. Режим доступу : http://zakon3.rada.gov.ua/laws/ show/994 962

2. Прокопов В.О. Наукові та практичні питання забезпечення населення України якісною питною водою. Гігієнічна наука та практика на рубежі століть : матер. XIV з'їзду гігієністів України. Дніпропетровськ : АРТ-ПРЕС, 2004. Т.1.

4. Особливо небезпечним $€$ забруднення води нітратами, які можуть спричинити воднонітратну метгемоглобінемію. Вищим за середньообласний цей показник був у Володимирецькому, Гощанському, Здолбунівському, Корецькому, Костопільському та Радивилівському районах.

5. Середньообласний показник невідповідності проб питної води із джерел децентралізованого водопостачання за міробіологічними показниками за досліджуваний період дещо збільшився і становив 29,0\% у 2015 р. порівняно з 25,8\% у 2004 p.

6. Вище за середньообласний відсоток невідповідності питної води із джерел децентралізованого водопостачання за мікробіологічними показниками був у Володимирецькому, Гощанському, Здолбунівському, Костопільському, Острозькому, Сарненському районах та у м. Рівне.

7. Недопущення виникнення і поширення інфекційних захворювань, протозоозів серед населення можливе лише за умови проведення комплексних заходів, якими передбачатимуться, окрім санітарногігієнічного моніторингу за якістю питної води, контроль стану утримання криниць і настороженість населення та медичного персоналу лікувально-профілактичних закладів стосовно діагностики, лікування та профілактики.

8. У контексті розбудови системи громадського здоров'я в Україні потребують подальшого продовження роботи 3 визначення кореляційних взаємозв'язків між якістю питної води та станом захворюваності населення області.

ЛІТЕРАТУРА

1. Директива $2000 / 60 / € C$ Європейського Парламенту і Ради "Про встановлення
C. $109-111$.

3. Гончарук Є.Г., Бардов В.Г., Гаркавий C.І. Яворовський О.П. та ін. Комунальна гігієна : підручник. Київ : Здоров'я, 2003. С. 50-52.

4. Avery A.A. Infantile

Methemoglobinemia:

Reexamining the Role of

Drinking Water Nitrates.

Environ. Health Persp.

1999. Vol. 107, № 7.

P. 583-586.

5. Fewtrell L. Drinking water nitrate, methemoglobinemia and global burden of disease: a discussion. Environ. Health Persp. 2004. Vol. 112 (14).

P. 1371-1374.

6. Ліхо О.Ф., Гакало О.І. Гущук І.В. Оцінка забруднення нітратами децентралізованих джерел водопостачання

у Рівненській області.

Вісник Нац. ун-ту водного господарства та природокористування. Рівне, 2010. № 1 (49).

С. $106-111$.

7. Федоренко В.І. ко-біологічні аспекти безсимптомної метгемоглобінемії у дітей. Довкілля та здоров'я. 2014. № 1 (68). С. 10-14

8. Винарська О.І., Спаська Ю.С., Григоренко Л.Є. та ін. Динаміка змін імунологічних показників за дії нітриту натрію з різними ксенобіотиками. Довкілля та здоров'я. 2013. № 4 (67). С. 14-19.

9. Гущук І.В., Брезецька О.І., Гущук B.I., Драб P.P.

Моніторинг за станом водозабезпечення міського населення Рівненської області за 19992015 роки. Довкілля та здоров'я. 2017. № 4 (84). С. 31-37.

10. Волощук О.В., Антомонов М.Ю., Гущук І.В. Аналіз рівня захворюваності населення Рівненської області.

Довкілля та здоров я. 2017. № 1 (81). С. 27-31.
Кіцула Л.М. Гігієнічні та меди-
REFERENCES

1. DIRECTIVE $2000 / 60 / E C$ OF THE EUROPEAN PARLIAMENT AND OF THE COUNCIL of 23

October 2000 Establishing a

Framework for Community Action in the Field of Water Policy. Official Journal of the

European Communities.

22.12.2000; L327/1-72.

2. Prokopov V.O. Naukovi ta praktychni pytannia zabezpechennia naselennia Ukrainy yakisnoiu pytnoiu vodoiu [Scientific and Practical Issues of the Provision of the Population of Ukraine with the Qualitative Drinking Water]. In : Hihiienichna nauka ta praktyka na rubezhi stolit : mater. XIV zizdu hihiienistiv Ukrainy [Hygienic Science and Practice at the Turn of Centuries: Mater. XIV Congress of the Hygienists of Ukraine]. Dnipropetrovsk : ART-PRES; 2004 ; 1 : 109-

111(in Ukrainian).

3. Honcharuk Ye.G., Bardov V.G., Harkavyi S.I., Yavorovskyi O.P. et al. Komunalna hihiiena : pidruchnyk [Communal Hygiene : Manual ]. Kyiv : Zdorovia ; 2003 : 50-52 p. (in Ukrainian).

4. Avery A.A. Environ. Health Persp. 1999 ; 107 (7) : 583-586.

5. Fewtrell L. Environ. Health Persp. 2004 ; 112 (14) : 1371 1374.

6. Likho O.F., Hakalo O.I. and Hushchuk I.V. Otsinka zabrudnennia nitratamy dezentralizovanykh dzherel vodopostachannia v Rivnenskii oblasti

[Assessment of the Nitrate Contamination of Decentralized Water Supply Sources in Rivne Oblast]. In : Visnyk

Natsionalnoho universytetu vodopostachannia ta pryrodokorystuvannia [Bulletin of National University of Water and Environment Engeneering]. Rivne, Ukraine ; 2010 ; 1 (49) : 106-111(in Ukrainian)

7. Fedorenko V.I. and Kitsula L.M. Dovkillia ta zdorovia. 2014 ; 1 (68) : 10-14 (in Ukrainian).

8. Vynarska O.I., Spaska Yu.S., Hryhorenko L.Ye. et al. Dovkillia ta zdorovia. 2013 ; 4 (67) : 14-19 (in Ukrainian)

9. Hushchuk I.V., Brezetska O.I., Hushchuk V.I. and Drab R.R. Dovkillia ta zdorovia. 2017 ; 4 (84) : 31-37 (in Ukrainian).

10. Voloshchuk O.V., Antomonov M.Yu. and Hushchuk I.V. Dovkillia ta zdorovia. 2017 ; 1(81) : 27-31 (in Ukrainian).

Надійшла до редакції 12.11.2017 